\title{
A new synonym and seventeen new distributional records in South American Cerambycidae (Coleoptera), with notes on Chlorethe scabrosa Zajciw, 1963
}

\author{
Antonio Santos-Silva ${ }^{1,3}$; Juan Pablo Botero ${ }^{1,4}$; Francisco Eriberto de Lima Nascimento ${ }^{1,5}$ \& Weliton Dias Silva ${ }^{2}$ \\ 1 Universidade de São Paulo (USP), Museu de Zoologia (MZUSP). São Paulo, SP, Brasil. \\ 2 Universidade de São Paulo (USP), Escola Superior de Agricultura “Luiz de Queiroz” (ESALQ), Departamento de Entomologia e Acarologia (LEA). \\ Piracicaba, SP, Brasil. ORCID: http://orcid.org/0000-0001-9035-204X.E-mail: wdsilv@gmail.com \\ ${ }^{3}$ ORCID: http://orcid.org/0000-0001-7128-1418. E-mail: toncriss@uol.com.br \\ ${ }^{4}$ ORCID: http://orcid.org/0000-0002-5547-7987. E-mail:jp_bot@yahoo.com \\ ${ }^{5}$ ORCID: http://orcid.org/0000-0002-5047-8921. E-mail: eribnascimentofl@gmail.com
}

\begin{abstract}
We studied 18 cerambycid beetle species native to South America. Seventeen represent new state records in Brazil. Particularly, Chlorethe scabrosa Zajciw, 1963 is newly reported for the state of Rio de Janeiro with exclusion of C. brachyptera Zajciw, 1963. The Brazilian state of the type locality of Dufauxia guaicurana Lane, 1955 is fixed. Pirangoclytus mendosus (Galileo \& Martins, 1996) is synonymized with P. mniszechii (Chevrolat, 1862), and its holotype is a female. Variation on Trypanidius maculatus Monné \& Delfino, 1980 is commented. New country and department records for Paraguay are also provided.
\end{abstract}

Key-Words. Brazilian savanna; Longhorned beetles; Paraguay; Semiochemical traps; Taxonomy.

\section{INTRODUCTION}

Cerambycidae comprises one of the largest beetle families with over 36,000 species described worldwide (reviewed by Monné et al., 2017). Many species play critical role in maintenance of health of ecosystems, for instance by acting as primary wood decomposers or by serving as food source for other animals (Monné et al., 2017). Moreover, some cerambycid species may represent serious pests for agriculture and forestry, especially when they are out of their native geographic range (Eyre \& Haack, 2017).

Within this context, crescent researches have been focused on development of strategies for the delineation of geographic distribution of native and exotic cerambycid species. Promising results have been obtained using semiochemical baited traps, especially with pheromone volatiles, for detection, monitoring, and management of cerambycid beetles (Millar \& Hanks, 2017).

Particularly in Brazil, field bioassays comprising use of semiochemical traps are part of an ongoing project that aims to study the pheromone chemistry of South American cerambycid beetles. The last author of the present paper is conducting this project since 2014 and some findings have been published elsewhere (Silva et al., 2016a, b; Silva et al., 2017; Silva et al., 2018a, b).

During the abovementioned bioassays conducted in Midwestern and Southeastern Brazil from 2015 to 2018, 17 non-target cerambycid species were caught. Surprisingly, 16 of them were noted as new state records for this country, and one was recognized as a new synonym. These findings offered the main framework for the present paper.

During identification of cerambycids from other collection source, a specimen of Chlorethe Bates, 1867, which remained in doubtful identity, was studied. However, because we came across a misidentification involving C. scabrosa Zajciw, 1963 and C. brachyptera Zajciw, 1963, we decided to include here the fix for this issue.

\section{MATERIAL AND METHODS}

Adult beetles representing most of the cerambycid species in this paper were collected with cross-vane intercept panel traps (black corrugated plastic) deployed in forest remnants of Cerrado from the Brazilian states of São Paulo (cities of Anhembi and Valentim Gentil) and Mato Grosso do Sul (city of Cassilândia). Semiochemicals (pher- 
omone and plant volatiles) and UV light were used as attractants. Except for Psapharochrus maculatissimus (Bates, 1861) (i.e., Silva et al., 2019), it is noteworthy to point that cerambycid species reported here were caught at random by the treatment traps and at insufficient numbers for statistics (data not shown).

Specimens from other sources were also examined and their records were provided.

The references under Pirangoclytus mniszechii (Chevrolat, 1862) and Chlorethe scabrosa (Zajciw, 1963) are restricted to the original descriptions and catalogues of Monné (2019a, b).

Photographs of habitus from representative specimens were taken with a Canon EOS Rebel T3i DSLR camera, Canon MP-E 65 mm f/2.8 1-5X macro lens, controlled by Zerene Stacker AutoMontage software.

The map depicting the new distributional records was made using the program MapCreator 2.0 Studio.

The acronyms used in the text are as follows: ESALQ = Escola Superior de Agricultura "Luiz de Queiroz", Departamento de Entomologia e Acarologia, Piracicaba, São Paulo, Brazil. MZSP = Museu de Zoologia, Universidade de São Paulo, São Paulo, Brazil.

Field collections of cerambycid beetles made by the last author at Anhembi, Cassilândia, and Valentim Gentil were conducted under the SISBIO permit № \#46395-2 from the Brazilian Ministry of the Environment. The study of cerambycid beetles from these locations was registered with the National System for the Management of Genetic Heritage and Associated Traditional Knowledge (Sisgen, Brazil) under № \#AE3897B.

\section{RESULTS}

Seventeen of the 18 cerambycid species reported here represent new records for the Brazilian states of Mato Grosso do Sul (1), Rio de Janeiro (1), and São Paulo (15). Another species represents a new synonym and a new department record for Paraguay. Additionally, one of the new records for the state of São Paulo (Brazil) is also a new country record for Paraguay.

These species belong to the subfamilies Cerambycinae and Lamiinae, and their respective tribes (sometimes subtribes) are shown. Specimens from species representing new state records for Brazil or a new synonym, and that were collected with attractant traps are indicated with "semiochemical/light trap" within bracket. New synonym and distributional records are indicated in bold font within parentheses.

CERAMBYCINAE Latreille, 1802

CERAMBYCINI Latreille, 1802

SPHALLOTRICHINA Martins \& Monné, 2002

Sphallotrichus sericeotomentosus Fragoso, 1995

Fig. 1

Material examined: BRAZIL, Mato Grosso do Sul (new state record): Cassilândia $\left(19^{\circ} 05^{\prime} 31.2^{\prime \prime} \mathrm{S}, 51^{\circ} 48^{\prime} 56.9^{\prime \prime} \mathrm{W}\right)$, [semiochemical trap], 3 males, 1 female, 03.III.2017, S.R. Rodrigues col. (ESALQ).

Geographical distribution: This species was described from Brazil (Mato Grosso, Rondônia, and Pará) and Bolivia (Santa Cruz). Currently, it is also known from the Brazilian states of Amazonas, Maranhão, and Goiás (Monné, 2019a). Additionally, Bezark (2019) listed this species in Venezuela, a country record previously presented by Monné \& Hovore (2005).

\section{CLYTINI MULSANT, 1839 Pirangoclytus mniszechii (Chevrolat, 1862)} Figs. 2-8

Mecometopus mniszechii Chevrolat, 1862: 64; Monné, 2019a: 150 (cat.).

Mecometopus mendosus Galileo \& Martins, 1996: 58; Monné, 2019a: 150 (cat.). Syn. nov.

Material examined: BRAZIL, Espírito Santo: Barra do São Francisco (Córrego Itá), 2 males, 1 female, paratypes of M. mendosus, XI.1956, Zikán col. (MZSP); rio Guandú, 1 paratype female of $M$. mendosus, X.1920, F. Hoffmann col. (MZSP). Rio de Janeiro: Rio de Janeiro, 1 paratype male of M. mendosus, X.1934, B. Pohl col. (MZSP). Minas Gerais: Mar de Espanha, 1 paratype male of $M$. mendosus, 15.XI.1907, Zikán col. (MZSP); 1 paratype male of M. mendosus, 29.XI.1909, Zikán col. (MZSP); Coronel Pacheco, 1 female, I.1956, V. Gomes col. (MZSP); Parque Estadual do Rio Doce, 1 female, XI.2014, L. Migliore col. (MZSP). São Paulo: Anhembi $\left(22^{\circ} 42^{\prime} 20.8^{\prime \prime} \mathrm{S}, 48^{\circ} 10^{\prime} 01.4^{\prime \prime} \mathrm{W}\right)$, [semiochemical trap], 1 female, 11.XII.2018, W.D. Silva col. (ESALQ); [Guarulhos] (22 $\left.71^{\prime} 52.32^{\prime \prime} \mathrm{S}, 48^{\circ} 15^{\prime} 89.65^{\prime \prime} \mathrm{W}\right), 1$ male, $1 \mathrm{fe}-$ male, 06.V.2013, E.N. Lopes col. (MZSP); Itu (Fazenda Pau d'Alho), 1 female (holotype of M. mendosus), 10.XI.1970, Monné col. (MZSP); Guarujá, 1 paratype male of $M$. mendosus, 10.XI.1920, Melzer col. (MZSP); Iguape, 1 paratype male of M. mendosus, XII.1921, A.C. Braole col. (MZSP); Campinas, 1 paratype male of $M$. mendosus, XI.1919, Merbach col. (MZSP); São Paulo (Saúde), 1 paratype male of M. mendosus, 13.XI.1921, Melzer col. (MZSP). Santa Catarina: Joinville, 1 paratype male of $M$. mendosus, 1916, Sohmalz col. (MZSP); Rio Vermelho, 1 paratype male of M. mendosus, Dirings (MZSP). PARAGUAY, Distrito Capital: Asunción, 1 paratype female of M. mendosus, 18.IX.1976, B. Aranda col. (MZSP). Cordillera (new department record): San Bernardino, 1 male, IX.1922, K. Friebrig col. (MZSP).

Geographical distribution: Currently, it is known from Brazil (Espírito Santo, Rio de Janeiro, São Paulo, Paraná, Santa Catarina, and Rio Grande do Sul) (Monné, 2019a).

Remarks: Chevrolat (1862) described Mecometopus mniszechii from Brazil without a specific locality. Monné et al. (2009) have first provided a detailed place for this species (Brazil, Rio de Janeiro, Itatiaia). Later, Galileo \& Martins (1996) described M. mendosus from Brazil (São Paulo, Minas Gerais, Espírito Santo, Rio de Janeiro, Santa Catarina) and 
Paraguay. Di lorio (2006) synonymized M. mendosus with M. mniszechii, but Martins \& Galileo (2011: 191) revalidated the species (translated): "Di lorio (2005, est. 47, fig.9) illustrated in color Pirangoclytus insignis under the denomination of M. mendosus. However, the same author (2006: 12) erroneously considered Pirangoclytus mendosus as synonym of P. mniszechi [sic]"; and ahead, in the same work (translated, p. 196): “Di lorio (2006: 12) considered Mecometopus mendosus synonym of $M$. mniszechi [sic]. This synonymy is inaccurate because the elytral color patterns are different. In Pirangoclytus mniszechii the basal maculae of the elytra are much larger and are followed by a small lateral spot near to its apex; the sutural maculae at the front of the middle also are much larger and closer to the basal one." Nevertheless, we think that Di lorio (2006) was right. Firstly, the small yellowish pubescent spot on sides of anterior third may or may not be present. It is present in some paratypes of M. mendosus (Figs. 5, 7, 8), and not only in a paratype as pointed out in the original description. Furthermore, when present, it is variable in size. Moreover, the size and shape of the elytral pubescent maculae (Figs. 2, 4, 5, 7, 8) are very variable in this species. Accordingly, the arguments by Martins \& Galileo (2011) are not consistent.

Dilorio (2006:13) reported: "Mecometopusmendosus and the true Mecometopus palmatus (of Olivier, 1795) can be differentiated by the pubescence of sternites $1^{\circ}$ and $2^{\circ}$, which is of a yellow color in Mecometopus mendosus, and white in Mecometopus palmatus (Galileo \& Martins, 1996). The description of "Mecometopus palmatus" given by Laporte \& Gory (1836: 84-85) says clearly"abdomen noir, avec les deux premiers segments et une tache de chaque côté du mesothorax d'un beau jaune". According to this, the reference of Laporte \& Gory (1836) must be referred to Mecometopus mendosus. This character, abdominal pubescence of white or yellow color, is of uncertain value to the determination of specimens: many Clytini exhibit variable coloration of the integument, and of the pubescent bands or spots [...]. Large series of specimens from different localities often are needed to clearly establish taxonomic status." These statements are somewhat confused. It is true that Laporte \& Gory (1836) described the ventral pubescence in Mecometopus palmatus as being yellow. We agree with him regarding the synonymy between M. palmatus sensu Laporte \& Gory (1836) and $M$. mendosus, and also regarding the variation in the color of the pubescence. However, apparently Di lorio (2006) was suggesting that Mecometopus mniszechii may be also equal to M. palmatus (Olivier, 1795). However, when present, the small yellow pubescent spot of the elytra in M. mniszechii (= Pirangoclytus mniszechii) is always placed at anterior third, while in M. palmatus it is placed about middle. Furthermore, although it is possible that these features are variable, in all specimens of $M$. palmatus the elytral apex is less oblique, and the anterior elytral pubescent band is elongate. Still according to Di lorio (2006: 15): "Only the extension of the abdominal yellow pubescence appears to differ slightly: on sternites I-III and part of IV in Mecometopus mniszechii (fide de [sic] Chevrolat, 1862a), and only on sternites I-II in Mecometopus mendosus." Actually, there are paratypes of M. mendosus with pubescence on ventrites III and IV (Fig. 6), not as dense as on I-II, but distinct.
The holotype of Mecometopus mendosus was described as being a male, but it is a female (Figs. 2-3).

\section{COMPSOCERINI Thomson, 1864 Chlorethe scabrosa Zajciw, 1963 Fig. 9}

Chlorethe scabrosa Zajciw, 1963: 418; Monné, 2019a: 174 (cat.).

Chlorethe brachyptera; Monné et al., 2016a: 346, fig. 23 (distr.); Monné et al., 2016b: 10 (distr.). (Misidentified).

Material examined: BRAZIL, [no further details]: 1 female, XII.1938, [no collector indicated] (MZSP).

Geographical distribution: Currently, C. scabrosa is known from Brazil (Mato Grosso do Sul, Espírito Santo, Paraná, Santa Catarina, and Rio Grande do Sul) and Argentina (Misiones) (Monné, 2019a).

Remarks: Chlorethe scabrosa was originally described from Brazil (Paraná and Mato Grosso [currently, Mato Grosso do Sul]). Monné et al. (2016a) and Monné et al. (2016b) reported C. brachyptera from the Brazilian state of Rio de Janeiro. However, the specimen figured by Monné et al. (2016a) is a male of C. scabrosa. Probably, the specimen mentioned by Monné et al. (2016b) is the same of Monné et al. (2016a). Accordingly, C. brachyptera is excluded from the fauna of Rio de Janeiro, and C. scabrosa is reported for the first time in this state.

\section{NEOIBIDIONINI Monné, 2012 TROPIDINA Galileo \& Martins, 2007 Tropidion rubricatum (Gounelle, 1909)} Fig. 10

Material examined: BRAZIL, São Paulo (new state record): Valentim Gentil $\left(20^{\circ} 22^{\prime} 24.7^{\prime \prime} \mathrm{S}, 50^{\circ} 05^{\prime} 17.8^{\prime \prime} \mathrm{W}\right)$, [semiochemical trap], 1 female, 17.X.2016, W.D. Silva col. (ESALQ); 2 females, 19.X.2016, W.D. Silva col. (ESALQ).

Geographical distribution: Tropidion rubricatum was described from Brazil (Goiás). Currently, it is known from Venezuela, Brazil (Goiás, Mato Grosso, and Minas Gerais), and Bolivia (Monné, 2019a).

\section{PIEZOCERINI Lacordaire, 1868 PIEZOCERINA Lacordaire, 1868 Piezocera costula Martins, 1976} Fig. 11

Material examined: BRAZIL, São Paulo (new state re-

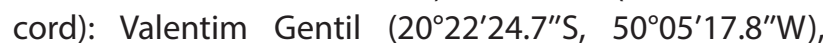
[semiochemical trap], 1 female, 02.X.2015, W.D. Silva col. (ESALQ); 1 male, 1 female, 25.XI.2015, W.D. Silva col. (ESALQ); 1 female, 22.XII.2015, W.D. Silva col. (ESALQ); 1 male, 1 female, 24.XII.2015, W.D. Silva col. (ESALQ). 

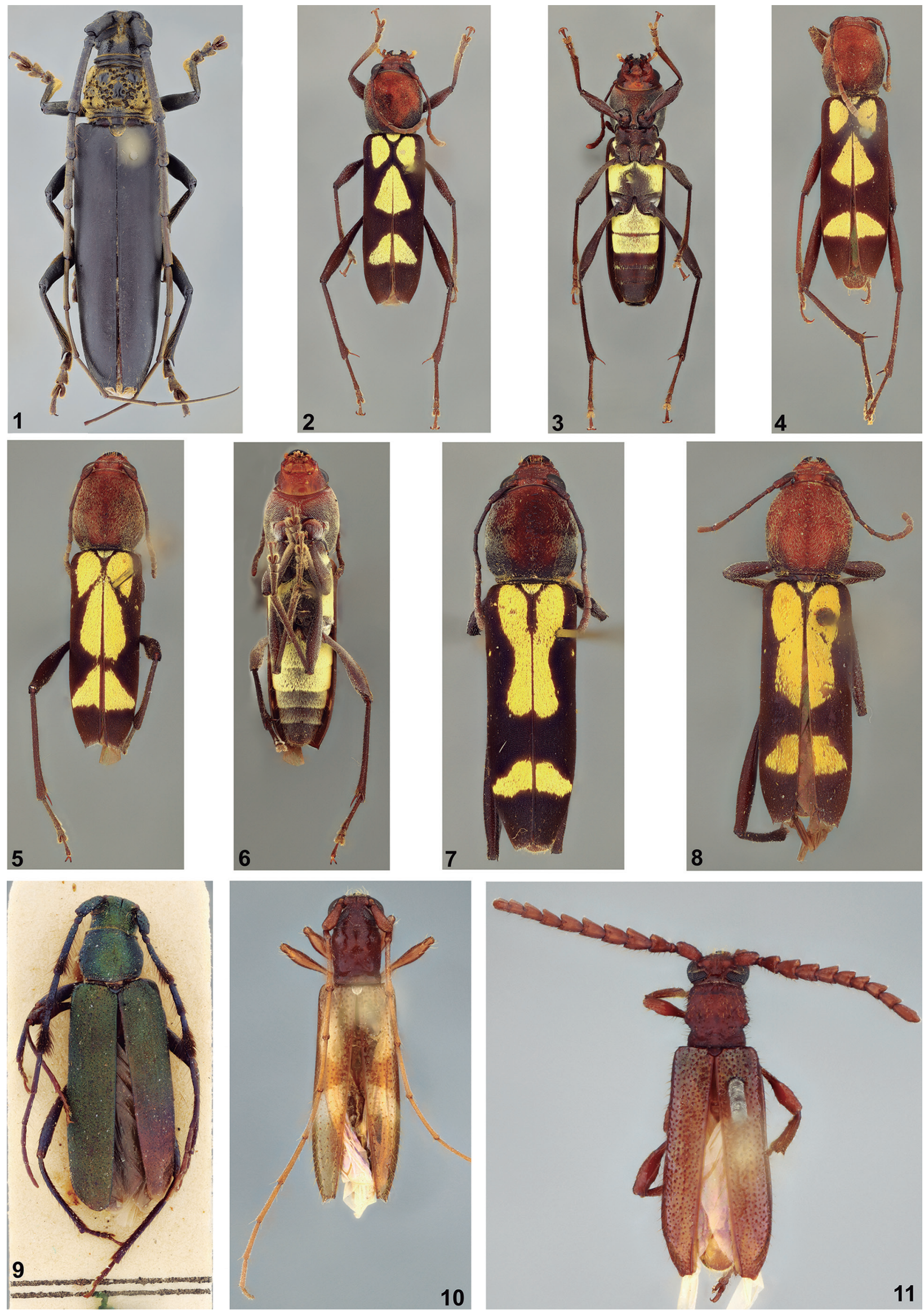

Figures 1-11. (1) Sphallotrichus sericeotomentosus, female, dorsal habitus. (2-8) Pirangoclytus mendosus: (2) holotype female, dorsal habitus; (3) holotype female, ventral habitus; (4) paratype 1, female, dorsal habitus; (5) paratype 2, female, dorsal habitus; (6) paratype 2, female, ventral habitus; (7) paratype 3, male, dorsal habitus; (8) paratype 4, male, dorsal habitus. (9) Chlorethe scabrosa, female, dorsal habitus. (10) Tropidion rubricatum, female, dorsal habitus. (11) Piezocera costula, female, dorsal habitus. 
Geographical distribution: This species was described from Brazil (Mato Grosso do Sul). Currently, it is known from Bolivia (Santa Cruz) and Brazil (Mato Grosso do Sul) (Monné, 2019a).

\section{SMODICINI Lacordaire, 1868 Smodicum semipubescens Gounelle, 1911}

Fig. 12

Material examined: BRAZIL, São Paulo (new state record): Valentim Gentil (20²2'24.7"S, 5005'17.8'W), [light trap], 1 male, 12.X.2018, W.D. Silva col. (ESALQ); 2 females, 11.X.2108, W.D. Silva col. (ESALQ).

Geographical distribution: Smodicum semipubescens was described from Peru and Brazil (Goiás). Currently, it is known from Peru, Bolivia (Santa Cruz), Brazil (Goiás), Paraguay, and Argentina (Salta, La Rioja, Mendoza, and Buenos Aires) (Monné, 2019a).

\section{LAMIINAE LATREILLE, 1825 ACANTHOCININI Blanchard, 1845 Leptostylus gnomus Monné \& Hoffmann, 1981} Fig. 13

Material examined: BRAZIL, São Paulo (new state record): Valentim Gentil $\left(20^{\circ} 22^{\prime} 17.7^{\prime \prime} \mathrm{S}, 50^{\circ} 04^{\prime} 46.6^{\prime \prime} \mathrm{W}\right)$, [semiochemical trap], 1 female, 05.XII.2016, W.D. Silva col. (ESALQ); 1 male, 15.Il.2015, W.D. Silva col. (MZSP).

Geographical distribution: This species was described from Brazil (Minas Gerais), Paraguay, and Argentina. Currently, it is also known from Bolivia (Santa Cruz) (Monné, 2019b).

\section{Lepturges (Lepturges) limpidus Bates, 1872} Fig. 14

Material examined: BRAZIL, São Paulo (new state record): Valentim Gentil $\left(20^{\circ} 22^{\prime} 25.8^{\prime \prime} \mathrm{S}\right.$, 500.'17.9'W), [semiochemical trap], 1 male, 26.X.2015, W.D. Silva col. (ESALQ); 2 females, 31.X.2015, W.D. Silva col. (ESALQ).

Geographical distribution: This species was described from Nicaragua. Currently, it is known from Mexico (Jalisco and Veracruz), Guatemala, Honduras, El Salvador, Nicaragua, Costa Rica, Panama, Colombia, Brazil (Pará, Mato Grosso, Espírito Santo, Paraná, and Santa Catarina), Peru, Bolivia (Beni, Santa Cruz, Tarija), and Paraguay (Monné, 2019b; Barros et al., 2019).

\section{Lepturges (Lepturges) perelegans Bates, 1863} Fig. 15

Material examined: BRAZIL, São Paulo (new state record): Valentim Gentil $\left(20^{\circ} 22^{\prime} 25.8^{\prime \prime} \mathrm{S}, 50^{\circ} 05^{\prime} 17.9^{\prime \prime} \mathrm{W}\right)$, [se- miochemical trap], 1 female, 10.XI.2015, W.D. Silva col. (ESALQ); 1 female, 27.XI.2015, W.D. Silva col. (ESALQ).

Geographical distribution: Lepturges perelegans was originally described from Brazil (Amazonas). Currently, it is known from Brazil (Amazonas, Pará, Mato Grosso, and Maranhão) (Monné, 2019b).

\section{Trypanidius maculatus Monné \& Delfino, 1980} Figs. 16-18

Material examined: BRAZIL, São Paulo (new state record): Valentim Gentil $\left(20^{\circ} 22^{\prime} 25.8^{\prime \prime} \mathrm{S}, 50^{\circ} 05^{\prime} 17.9^{\prime \prime} \mathrm{W}\right)$, [semiochemical trap], 1 female, 10.XII.2016, W.D. Silva col. (ESALQ); $\left(20^{\circ} 22^{\prime} 17.3^{\prime \prime} \mathrm{S}, 50^{\circ} 04^{\prime} 47.4^{\prime \prime} \mathrm{W}\right), 1$ male, 1 female, 03.XII.2018, W.D. Silva col. (ESALQ); 1 female, 12.XII.2018, W.D. Silva col. (ESALQ).

Geographical distribution: Trypanidius maculatus was described from Venezuela, Brazil (Pará and Mato Grosso), and Paraguay (Monné, 2019b).

Remarks: The narrow oblique pubescent band adjacent to the black oblique band on anterior quarter of the elytra may be whitish or pale yellow (Fig. 17) or distinctly yellow (Fig. 18), well-delimited (Fig. 18) or somewhat irregular (Fig. 16); the two black posterior pubescent spots on pronotum may be distinct (Fig. 16) or nearly absent (Fig. 18).

\section{ACANTHODERINI Thomson, 1860 Aegoschema moniliferum (White, 1855)}

Fig. 19

Material examined: BRAZIL, São Paulo (new state record): Valentim Gentil $\left(20^{\circ} 22^{\prime} 17.3^{\prime \prime} \mathrm{S}, 50^{\circ} 04^{\prime} 47.4^{\prime \prime} \mathrm{W}\right)$, [semiochemical trap], 1 female, 30.XI.2018, W.D. Silva col. (ESALQ); Luiz Antonio (Estação Ecológica Jataí; $21^{\circ} 36^{\prime} 47^{\prime \prime} \mathrm{S}, 47^{\circ} 43^{\prime} 43^{\prime \prime} \mathrm{W}$; mata ciliar), 2 females, XII.2007, Lara \& Perioto col. (MZSP); 1 male, 1 female, VII.2008, Lara \& Perioto col. (MZSP).

Geographical distribution: Aegoschema moniliferum was described from Brazil (Pará). Currently, it is known from French Guiana, Brazil (Roraima, Amazonas, Pará, Rondônia, Mato Grosso, Goiás, Maranhão, and Ceará), Peru, Bolivia (Pando and Santa Cruz) (Monné, 2019b), and Colombia (Meta) (Nascimento \& Botero, 2018).

\section{Dufauxia guaicurana Lane, 1955} Fig. 20

Material examined: BRAZIL, São Paulo (new state record): Valentim Gentil (20²2'17.7'S, 5004'46.6"W), [semiochemical trap], 1 female, 01.X.2016, W.D. Silva col. (ESALQ); 1 male, 23.IX.2016, W.D. Silva col. (ESALQ); $\left(20^{\circ} 22^{\prime} 25.8^{\prime \prime} \mathrm{S}, 50^{\circ} 05^{\prime} 17.9^{\prime \prime} \mathrm{W}\right), 1$ male, 24.IX.2018, W.D. Silva col. (ESALQ). 

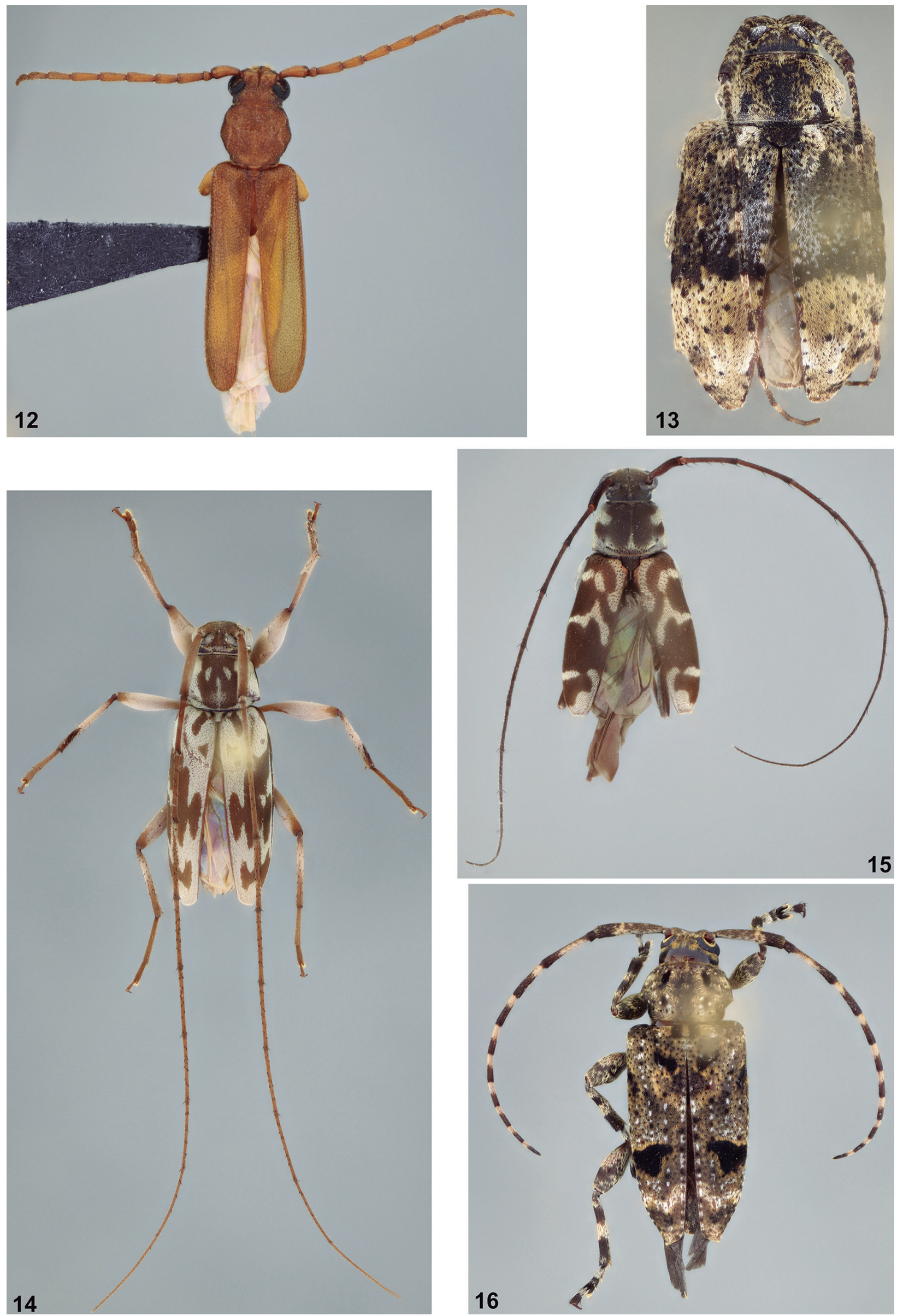

Figures 12-16. Dorsal habitus. (12) Smodicum semipubescens, female. (13) Leptostylus gnomus, female. (14) Lepturges (Lepturges) limpidus, female. (15) Lepturges (Lepturges) perelegans, female. (16) Trypanidius maculatus, female. 

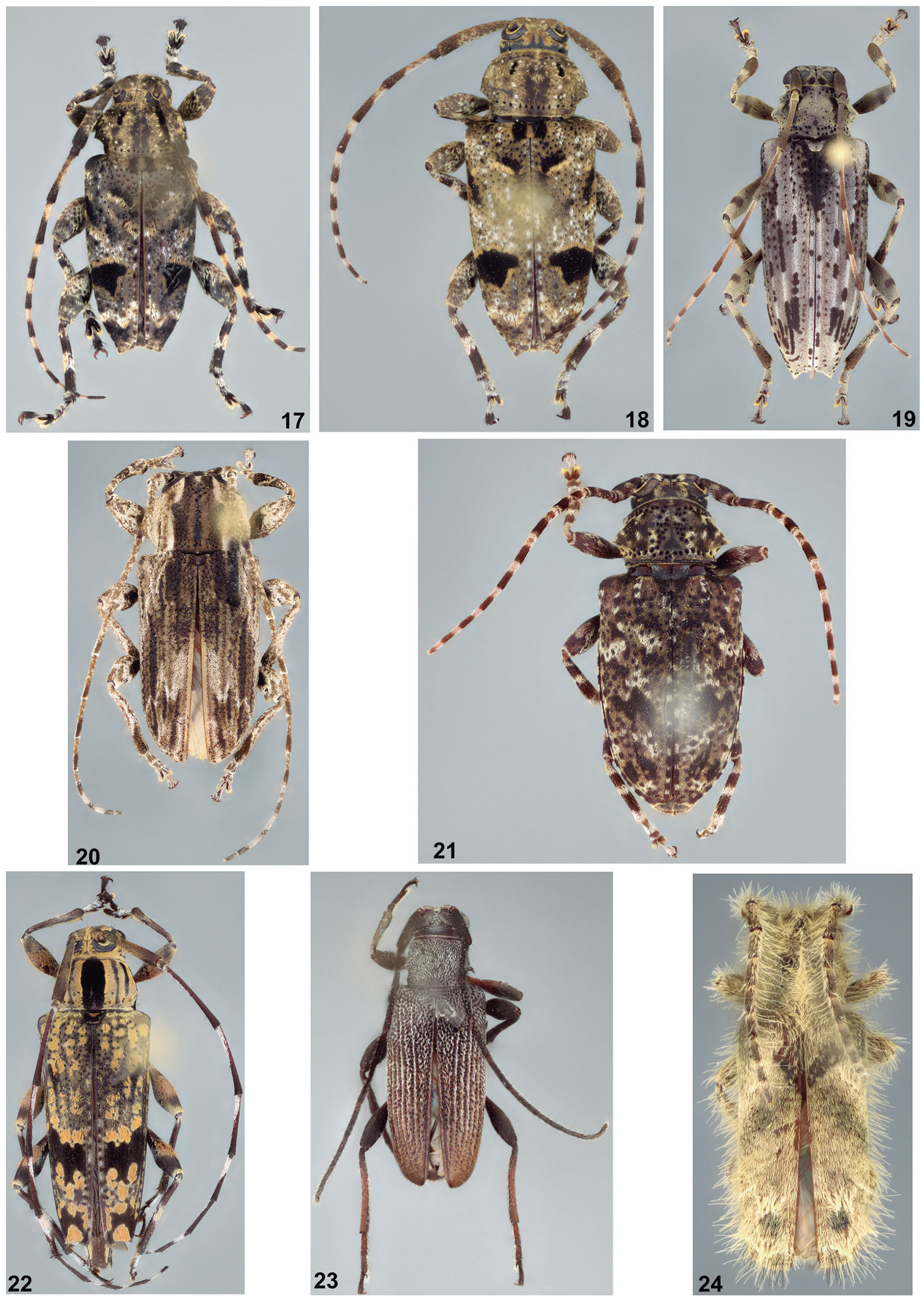

Figures 17-24. Dorsal habitus. (17-18) Trypanidius maculatus: (17) male; (18) female. (19) Aegoschema moniliferum, female. (20) Dufauxia guaicurana, female. (21) Psapharochrus maculatissimus, female. (22) Colobothea centralis, female. (23) Cicuiara striata, male. (24) Desmiphora (Desmiphora) pallida, femea. 
Geographical distribution: Currently, this species is known from the Brazilian states of Rondônia (Monné \& Magno, 1990) and Mato Grosso, and Bolivia (Beni, Santa Cruz) (Wappes et al., 2006).

Remarks: Dufauxia guaicurana was described from Brazil (Mato Grosso, "Guaicurus, km 1221 da E.F.N.O.B."). Guaicurus was a railway station of the "Estrada de Ferro Noroeste do Brazil". This railway station was located in the municipality of Miranda, which, at that time, belonged to the Brazilian state of Mato Grosso. However, in 1977 Mato Grosso was divided into two states: Mato Grosso and Mato Grosso do Sul. Miranda is currently placed in the latter. Accordingly, the state of the type locality of D. guaicurana needs to be fixed. Since there is no evidence that citations of the species in Mato Grosso after the original description were based on specimens collected in this state, but only in the original description, the species is formally excluded from the fauna of this Brazilian state.

\section{Psapharochrus maculatissimus (Bates, 1861)} Fig. 21

Material examined: BRAZIL, São Paulo (new state re-

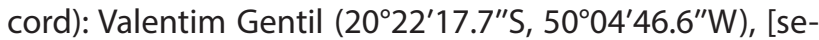
miochemical trap], 1 female, 02.X.2016, W.D. Silva col. (ESALQ); 2 females, 19.X.2017, W.D. Silva col. (ESALQ).

Geographical distribution: Psapharochrus maculatissimus was originally described from Brazil (Pará). Currently, it is known from Brazil (Pará, Mato Grosso, and Goiás), Bolivia (Cochabamba and Santa Cruz) (Monné, 2019b). Zajciw (1968) recorded this species from Peru. This latter country was present in Monné (1994), but was omitted in Monné (2005, 2019b). Works excluding this species from Peruvian fauna are unknown. Furthermore, the work by Zajciw (1968) appears in Monné $(2005,2019 b)$ under references of $P$. maculatissimus.

Remarks: The last author collected this species in 2016 in a remnant of Cerrado at Valentim Gentil. In that occasion, conspecific adults of both sexes were caught with traps baited with general attractant pheromones for cerambycid beetles. Living adult beetles were used to obtain the attractant pheromone of the species and the results will be published elsewhere (i.e., Silva et al., 2019).

\section{COLOBOTHEINI Thomson, 1860 Colobothea centralis Monné, 1993}

Fig. 22

Material examined: BRAZIL, São Paulo (new state record): Valentim Gentil $\left(20^{\circ} 22^{\prime} 17.7^{\prime \prime} \mathrm{S}, 50^{\circ} 04^{\prime} 46.6^{\prime \prime} \mathrm{W}\right)$, [semiochemical trap], 1 female, 04.I.2017, W.D. Silva col. (ESALQ).

Geographical distribution: This species was described and remains known only from Brazil (Goiás) (Monné, 2019b).

\section{DESMIPHORINI Thomson, 1860 \\ Cicuiara striata (Bates, 1866)}

Fig. 23

Material examined: BRAZIL, São Paulo (new state record): Valentim Gentil $\left(20^{\circ} 22^{\prime} 25.8^{\prime \prime} \mathrm{S}\right.$, 50 05'17.9'W), [semiochemical trap], 1 male, 17.XI.2015, W.D. Silva col. (ESALQ). PARAGUAY (new country record): Alto Parana: Puerto Presidente Stroessner, 1 specimen, XII.1971, Peña col. (MZSP).

Geographical distribution: This species was described from Brazil (Pará). Currently, it is known from Venezuela, Brazil (Pará, Mato Grosso do Sul, Goiás, Maranhão, Piauí, Bahia and Minas Gerais), and Bolivia (Santa Cruz) (Monné, 2019b).

\section{Desmiphora (Desmiphora) pallida Bates, 1874} Fig. 24

Material examined: BRAZIL, São Paulo (new state record): Valentim Gentil $\left(20^{\circ} 22^{\prime} 24.7^{\prime \prime} \mathrm{S}, 50^{\circ} 05^{\prime} 17.8^{\prime \prime} \mathrm{W}\right)$, [light trap], 1 female, 12.X.2018, W.D. Silva col. (ESALQ); Piraju, 1 female, VIII.1966, M. Carrera col. (MZSP); Barueri, 1 male, 04.XII.1955, K. Lenko col. (MZSP); 1 male, 05.XI.1960, K. Lenko col. (MZSP); 1 female, X.1965, K. Lenko col. (MZSP); Campinas, 1 female, II.1936, [illegible collector name] (MZSP); Rio Claro, 1 female, 23.XII.1942, F.S. Pereira col. (MZSP).

Geographical distribution: This species was described from Jamaica. Currently, it is known from Jamaica, Brazil (Goiás, Maranhão, Rio Grande do Norte, Piauí, Ceará, Bahia, Minas Gerais, Espírito Santo, and Rio de Janeiro), Peru, Bolivia (Santa Cruz), and Argentina (Tucumán) (Monné, 2019b).

\section{Estola alternata Breuning, 1940}

Fig. 25

Material examined: BRAZIL, São Paulo (new state record): Anhembi $\left(22^{\circ} 42^{\prime} 20.8^{\prime \prime} \mathrm{S}, 48^{\circ} 10^{\prime} 01.4^{\prime \prime} \mathrm{W}\right)$, [semiochemical trap], 1 female, 04.XII.2018, W.D. Silva col. (ESALQ).

Geographical distribution: Estola alternata was described from Brazil (Bahia). Currently, it is known from Brazil (Alagoas, Sergipe, and Bahia) (Monné, 2019b).

\section{Mimasyngenes lineatipennis Breuning, 1950}

Fig. 26

Material examined: BRAZIL, São Paulo (new state record): Valentim Gentil $\left(20^{\circ} 22^{\prime} 25.8^{\prime \prime} \mathrm{S}, 50^{\circ} 05^{\prime} 17.9^{\prime \prime} \mathrm{W}\right)$, [semiochemical trap], 1 female, 23.XI.2015, W.D. Silva col. (ESALQ).

Geographical distribution: This species was described from Argentina (Santiago del Estero). Currently, 

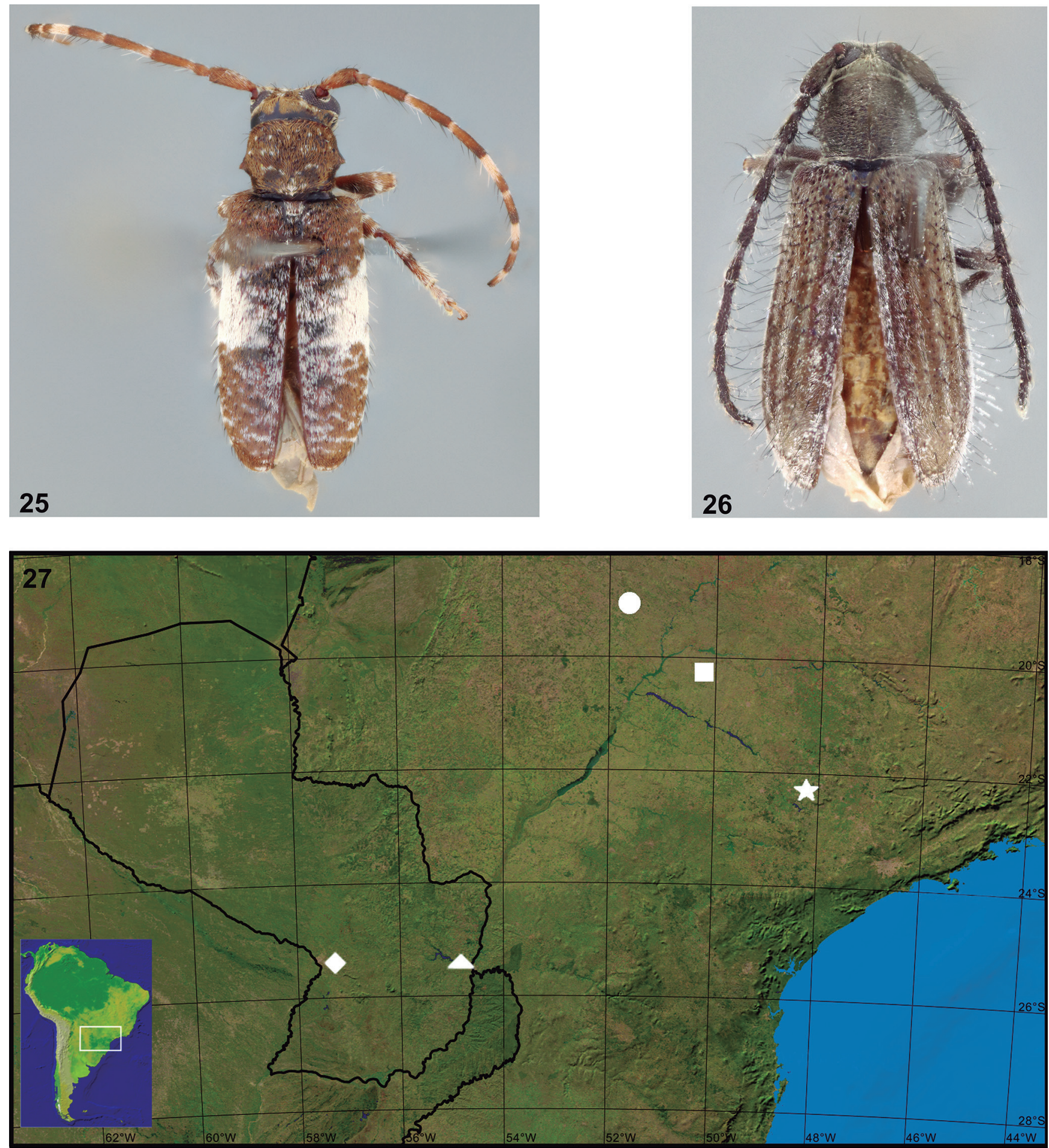

Figures 25-27. (25) Estola alternate, female. (26) Mimasyngenes lineatipennis, female. (27) Map indicating the locality of the new records: Circle, Brazil, Mato Grosso do Sul, Cassilândia; square, Brazil, São Paulo, Valentim Gentil; star, Brazil, São Paulo, Anhembi; triangle, Paraguay, Alto Paraná, Puerto Presidente Stroessner; rhombus, Paraguay, Cordillera, San Bernardino.

it is known from Brazil (Maranhão, Goiás, Pernambuco, Bahia, and Paraná), Bolivia (Santa Cruz), and Argentina (Santiago del Estero) (Monné, 2019b; Breuning, 1974).

\section{DISCUSSION}

Broadly speaking, most of the distributional records related here (15 cerambycid species) are from the Brazilian state of São Paulo. Remarkably, 10 of these spe- cies (i.e., Piezocera costula, S. semipubescens, L. (L.) perelegans, T. maculatus, A. moniliferum, D. guaicurana, Psapharochrus maculatissimus, C. centralis, E. alternate, and $M$. lineatipennis) were found to be new southeasternmost distributional records in Brazil. The remaining new records for Mato Grosso do Sul, São Paulo, and Rio de Janeiro have been previously reported for other states within the same geographic region. However, one of these species, C. striata, represents a new country record for Paraguay. 
Specimens representing most of the species reported here were collected with semiochemical traps, which have been demonstrated to be sensitive and efficient tools for detection of adult cerambycid beetles in different geographic regions (Millar \& Hanks, 2017).

\section{ACKNOWLEDGMENTS}

The authors gratefully acknowledge financial support from São Paulo Research Foundation (FAPESP) under grant numbers: \#2017/17898-0 (to JPB), \#2017/15283-9 (to FELN), and \#2013/26936-2 (to WDS); and from INCT-Semioquímicos na Agricultura (FAPESP grant \#2014/50871-0; CNPq grant \#465511/2014-7). Authors also thank to Dr. João Carlos T. Mendes and Dr. Sérgio R. Rodrigues for allowing accessing the forest remnants at Anhembi (Experimental Station of Forest Science - USP/ ESALQ), and at Cassilândia (UEMS campus), respectively. A special thank you to Dr. Jocelyn Millar (University of California, Riverside) and Lawrence Hanks (University of Illinois at Urbana-Champaign) for providing the pheromone attractants; and to Cassio D. Silva and Araci R. Silva for helping in the field collections.

\section{AUTHORS' CONTRIBUTIONS}

WDS: collected and prepared the specimens for taxonomy; AAS, JPB, and FELN: identified the species and revised the literature. AAS: took the photographs, designed the distributional map and prepared the figures. All authors wrote the manuscript and approved its submission.

\section{REFERENCES}

Barros, R.C.; Fonseca, M.G.; Vendramini, V.E. \& Júlio, C.E.A. 2019. Species of Lamiinae (Insecta, Coleoptera, Cerambycidae) from east Paraná State (Brazil), with new geographic records. Zootaxa, 4545(2): 179-204. D0I

Bezark, L.G. 2019. Checklist of the Oxypeltidae, Vesperidae, Disteniidae and Cerambycidae (Coleoptera) of the Western Hemisphere. 2019 Edition (updated through 31/12/2018). https://apps2.cdfa.ca.gov/publicApps/ plant/bycidDB/checklists/WestHemiCerambycidae2019.pdf. Access in: 15/07/2019.

Breuning, S. 1974. Révision des Rhodopinini américains. Studia Entomologica, 17(1-4): 1-210.

Chevrolat, L.A. 1862. Description des clytides du Brésil. Annales de la Société Entomologique de France, 2(4): 49-67.

Di lorio, 0. 2006. New records, synonymies and a new Clytini from South America (Coleoptera, Cerambycidae, Cerambycinae). Les Cahiers Magellanes, 58: 1-28.

Eyre, D. \& Haack, R.A. 2017. Invasive cerambycid pests and biosecurity measures. In:Wang, Q. (Ed.). Cerambycidae of the world: biology and pest management. CRC Press/Taylor \& Francis, Boca Raton, 563-618.

Galileo, M.H.M. \& Martins, U.R. 1996. Notas sinonímicas, dimorfismo sexual e descrição de nova espécie de Mecometopus Thomson, 1860 (Coleoptera, Cerambycidae, Cerambycinae, Clytini). Revista Brasileira de Entomologia, 40(1): 57-60.
Laporte, F.L.N. \& Gory, H.L. 1836. Monographie du genre Clytus. In: Gory, H. (Ed.). Histoire Naturelle et iconographie des insectes coléoptères, publié par monographies séparées. P. Duménil, Paris, Vol. 3, iii + 1-124, 20 pls. https://www.biodiversitylibrary.org/item/193087\#page/9/mode/1up.

Martins, U.R. \& Galileo, U.R.M. 2011. Clytini Mulsant, 1839. In: Martins, U.R. (Ed.). Cerambycidae Sul-americanos (Coleoptera), Taxonomia. Vol. 12. Sociedade Brasileira de Entomologia, Curitiba, 1-164.

Millar, J.G. \& Hanks, L.M. 2017. Chemical ecology of cerambycids. In: Wang, Q. (Ed.). Cerambycidae of the world: biology and pest management. CRC Press/Taylor \& Francis, Boca Raton, 161-208.

Monné, M.A. 1994. Catalogue of the Cerambycidae (Coleoptera) of the Western Hemisphere. Part XVII. Subfamily Lamiinae: Tribes Anisocerini, Polyrhaphidini, Xenofreini, Acrocinini and Acanthoderini. Sociedade Brasileira de Entomologia, São Paulo, 110 pp.

Monné, M.A. 2005. Catalogue of the Cerambycidae (Coleoptera) of the Neotropical Region. Part II. Subfamily Lamiinae. Zootaxa, 1023: 1-759.

Monné, M.A. 2019a. Catalogue of the Cerambycidae (Coleoptera) of the Neotropical region. Part II. Subfamily Cerambycinae. http://cerambyxcat. com. Access in: 26/07/2019.

Monné, M.A. 2019b. Catalogue of the Cerambycidae (Coleoptera) of the Neotropical region. Part II. Subfamily Lamiinae. http://cerambyxcat. com. Access in: 26/07/2019.

Monné, M.A. \& Hovore, F.T. 2005. Checklist of the Cerambycidae, or longhorned wood-boring beetles, of the Western Hemisphere. BioQuip Publications, Rancho Dominguez, $393 \mathrm{pp}$.

Monné, M.A. \& Magno, P.R. 1990. Novas espécies de Acanthoderini neotropicais I. (Coleoptera, Cerambycidae, Lamiinae). Revista Brasileira de Entomologia, 34(4): 687-691.

Monné, M.L.; Monné, M.A.; Botero, J.P. \& Carelli, A. 2016a. Two new species and new records of Cerambycidae (Insecta, Coleoptera) from Itatiaia National Park, Rio de Janeiro, Brazil. Zootaxa, 4137(3): 339-356. D0l

Monné, M.A.; Monné, M.L.; Carelli, A. \& Botero, J. 2016b. Cerambycidae (Insetos, Coleoptera) no Parque Nacional do Itatiaia. Boletim do Parque Nacional do Itatiaia, 24: 1-37.

Monné, M.L.; Monné M.A. \& Wang G. 2017. General morphology, classification, and biology of Cerambycidae. In:Wang, Q. (Ed.). Cerambycidae of the world: biology and pestmanagement. CRC Press/Taylor \& Francis, Boca Raton, 1-70.

Monné, M.L.; Monné, M.A. \& Mermudes, J.R.M. 2009. Inventário das espécies de Cerambycinae (Insecta, Coleoptera, Cerambycidae) do Parque Nacional do Itatiaia, RJ, Brasil. Biota Neotropica, 9(3): 1-30. DOI

Nascimento, F.E.L. \& Botero, J.P. 2018. New species, new records and notes in Cerambycidae from Colombia. Zootaxa, 4375(3): 426-432. D01

Silva,W.D.;Millar,J.G.;Hanks, L.M.\&Bento,J.M.S.2016a.10-Methyldodecanal, a novel attractant pheromone produced by males of the South American cerambycid beetle Eburodacrys vittata. PLOS ONE, 11: e0160727. DOI

Silva, W.D.; Millar, J.G.; Hanks, L.M. \& Bento, J.M.S. 2016b. (6E, 8Z)-6,8-pentadecadienal, a novel attractant pheromone produced by males of the cerambycid beetles Chlorida festiva and Chlorida costata. Journal of Chemical Ecology, 42: 1082-1085. D0I

Silva, W.D.; Bento, J.M.S.; Hanks, L.M. \& Millar, J.G. 2018a. (Z)-7-Hexadecene is an aggregation-sex pheromone produced by males of the South American cerambycid beetle Susuacanga octoguttata. Journal of Chemical Ecology, 44: 1115-1119. DOI

Silva, W.D.; Millar, J.G.; Hanks, L.M.; Costa, C.M.; Leite, M.O.G.; Tonelli, M. \& Bento, J.M.S. 2018b. Interspecific cross-attraction between the South American cerambycid beetles Cotyclytus curvatus and Megacyllene acuta is averted by minor pheromone components. Journal of Chemical Ecology, 44: 268-275. D01

Silva, W.D.; Zou, Y.; Bento, J.M.S.; Hanks, L.M. \& Millar, J.G. 2017. Aggregationsex pheromones and likely pheromones of 11 South American 
cerambycid beetles, and partitioning of pheromone channels. Frontiers in Ecology and Evolution, 5: 101. DOI

Silva, W.D.; Zou, Y.; Hanks, L.M.; Bento, J.M.S. \& Millar, J.G. 2019. Enantiomers of fuscumol acetate comprise the aggregation-sex pheromone of the South American cerambycid beetle Psapharochrus maculatissimus, and likely pheromones of the cerambycids Eupromerella plaumanni and Hylettus seniculus. Entomologia Experimentalis et Applicata, 167(11): 915-921. D0
Wappes, J.E.; Morris, R.F.; Nearns, E.H. \& Thomas, M.C. 2006. Preliminary checklist of Bolivian Cerambycidae (Coleoptera). Insecta Mundi, 20(1-2): 1-45.

Zajciw, D. 1963. Revisão do gênero Chlorethe Bates, 1867 (Col., Cerambycidae, (erambycinae). Anais da Academia Brasileira de (iências, 35(3): 413-419.

Zajciw, D. 1968. Novas ocorrências de Acanthoderes Serv., 1835 (Coleoptera, (erambycidae, Lamiinae). Atas da Sociedade de Biologia, 12(3): 141. 